Libri, 48 (4), December 1998, 187-211 [ISSN 0024-2667] [online]: ??? [Accessed ???]

\title{
The Mitterrand Library in context: the Bibliotheque Nationale de France and library provision in France
}

\author{
Sylvie C. Davies, and Ian M. Johnson
}

School of Information and Media, The Robert Gordon University, Garthdee Road, Aberdeen AB10 7QE, Great Britain (e.mail: sim@rgu.ac.uk)

\begin{abstract}
On 17 December 1996, President Chirac inaugurated a public reference library situated in the largest, costliest and most debated building erected in Paris in modern times. This building is part of a wider project, launched in 1988 by the late President Mitterrand, to create a library of a 'wholly new conception' which should cover all aspects of knowledge, be accessible to all and be electronically linked to the rest of the European library network. This project subsequently included the modernisation of the Bibliothèque Nationale and became the project of the Bibliothèque Nationale de France. This review aims to clarify the purpose of the building in the context of the existing French national library and the pattern of information services in France. The paper reviews the contextual elements before focusing on the building itself. These elements include the concept of national libraries in the modern information environment; an overview of the French library scene; the history of the project highlighting the factors which influenced the planning strategy; the legacy of the old Bibliothèque Nationale as well as the associated programme towards the creation of an online library service. The new building is described from a structural and operational view point and is evaluated in terms of its functionality as a library and in terms of its place in the context of the French national library. The review emphasises that the construction of such a building had a political purpose and suggests that its substantial operating cost combined with the policies of strict austerity imposed by the current French government are likely to jeopardise not only the efficiency of the new library itself, but also the modernisation of French library services.
\end{abstract}

\section{Introduction}

On $14^{\text {th }}$ July 1988, President François Mitterrand announced the launch of the latest of his Parisian projects in the following terms:

I want a library of a wholly new conception [...] a national library which can cover all aspects of knowledge in all its disciplines and that will communicate this knowledge to those who research, study and those who need to learn [...] one of the largest and technically advanced libraries in the world which would be connected with all major universities and research libraries in Europe and grant access to everyone regardless of professional status or formal activities [...] We shall then possess an unequalled tool 
for work and research. This is my ambition and I will accomplish it (quoted in Gattegno, 1992, p.16). ${ }^{1}$

This library building, in the east end of Paris near the Tolbiac bridge, is now part of the recently established Bibliothèque Nationale de France (BNF). It opened its doors to the public in December 1996.

The French national library can trace its origins back to the Sixteenth Century. In 1721, the Royal Librarian Bignon made the first transfer of the royal collections to a building in rue Richelieu close to the Louvre Palace. Napoleon III entrusted the rebuilding of some of the library's premises on the same site to the architect Henri Labrouste. Numerous improvements and extensions to these buildings to accommodate the catalogue and bibliography rooms, a periodical reading room, the Prints department, and the maps and plans. In addition, new buildings have been constructed nearby to house the Music Department and Sound Archives, the administrative departments, and the computer department. Additional collections are stored in two external buildings located in Paris, and although storage capacities have been greatly improved, it had become necessary to create annexes outside Paris, some of them situated in provincial cities several hundred kilometres from the capital. Once the Tolbiac building and an additional building at Marne-la-Vallée are fully operational, the Bibliothèque Nationale de France will operate on eight different sites.

Although Mitterrand's speech does not make any reference to the Bibliothèque Nationale (BN), it is reasonable to assume that no such project would have been envisaged without an awareness of the inadequacy of the services provided by this institution. On the other hand, the wording in the speech indicates that he had in mind a library fundamentally different from the BN. The absence of capital letters for 'bibliothèque nationale' in the official transcript suggests that it was not the intention of re-creating the BN on a larger scale, precisely because the BN did not possess any of the qualities enunciated by the President. It did not cover all aspects of knowledge; it was elitist in the choice of users; it had no information network with other libraries; and, technically, it was lagging behind its counterparts in Europe.

For want of not knowing the exact identity of the future library, French commentators and officials alike, soon labelled the project the 'Très Grande Bibliothèque' ${ }^{\text {. }}$. Simultaneously, the question arose: 'quelle très grande bibliothèque' (which very large library)? This question reflected the underlying concern of all interested parties as to the real nature and purpose of the Tolbiac building. Even today, the question is still pertinent.

The project of the Bibliothèque Nationale de France was a major undertaking. It cost 7.2 billion Francs with 5 billion allocated to the Tolbiac building alone (Bibliothèque de France, 1990). A number of question comes to mind:

- What is the significance of the building which could justify such an expense?

- What tasks is it expected to perform?

- What is its place in the existing French national library?

- How does the library fit in with the existing pattern of French library services?

\footnotetext{
${ }^{1}$ Author's translation.

2 'The Very Large Library'
} 
This review seeks to clarify the purpose of the building and its contribution to the development of French national information services in general and the modernisation of the French national library in particular. It will:

- examine the contemporary concept of the role of national libraries

- trace the development of the Tolbiac project, highlighting the factors which have influenced the planning strategy

- provide an overview of the French library network and how it relates to the Bibliothèque Nationale de France

- analyse the legacy of the Bibliothèque Nationale

- describe the Tolbiac building from a design, structural and operational view point

- evaluate the building in terms of its functionality as a library and in terms of its place in the context of the French national library.

Finally, on the basis that the review has provided sufficient elements to form a judgement, the paper will put forward an appraisal on the identity of the Tolbiac library and whether it is equipped to fulfil the objectives set out by its planners.

Although the planning of a national library can be seen as a political undertaking, the scope of this review does not permit a discussion of how the particularities of the French political system have influenced this particular project, as this would have taken the review too far into the complexities of the French government machine. The review used as a starting point French publications offering regular features on the progress of the BNF project, supplemented by visits to the documentation centre of the Direction du Livre et de la Lecture (DLL) of the Ministère de la Culture ${ }^{3}$ and interviews with officials of the DLL. The review was undertaken whilst the project of the Bibliothèque Nationale de France was still in train, and the available information has had to be considered with care. Even at the point of the completion of the review, which coincided with the opening of the Tolbiac building, certain statements had to be revised in the light of what has been revealed by the most recent facts or decisions taken by the management team.

\section{The evolution of the role of national libraries}

A review of the literature shows that it is easier to define a national library by listing its possible activities rather that looking for a model to follow. An outline of the evolution of the concept of a national library may give a better understanding of what is expected from a national library at the end of the $20^{\text {th }}$ century.

Until the $20^{\text {th }}$ century, the typical national library such as the such as the British Library and the $\mathrm{BN}$, was, or aimed to be, the national printed archive, systematically acquired, managed and catalogued. However, as the number of researchers grew, the problem of how to reconcile conservation and communication became a growing issue, the collection being the logical base for bibliographic, lending and information services, while the services were putting the collection in danger of deterioration (Esdaile, 1934). Issues relating to financing, the compilation of current and retrospective bibliographies, the need for innovation, diffusion versus centralisation of information, the training of personnel, and the problems of serving science and technology were identified in 1955 in a special number of the journal Library Trends devoted to national libraries (Mearns, 1955). Efforts to address these problems were

\footnotetext{
${ }^{3}$ Department of Books and Reading of the Ministry of Culture, responsible for the main national and public library services in France.
} 
then instigated by the International Federation of Library Associations (IFLA) which established a new Section on National Libraries.

Further impetus for concerted actions originated in the discussions at a symposium on national libraries organised by UNESCO which took place in Vienna in September 1958. For the first time, senior librarians and national library directors from every European country (except Greece) gathered to discuss the problems and the prospects of national libraries (UNESCO, 1960). Among the conclusions and recommendations agreed upon, some were specifically aimed at national libraries:

- it is the responsibility of the national library to acquire and conserve the whole of the national production of printed material

- it is recommended that a national plan for the acquisition of foreign materials should be established in countries where no such plan exists

- it is also the national library's responsibility to undertake the production of current national bibliographies, and also of retrospective national bibliographies where needed

- it is the responsibility of the national library to assemble material for a central register of manuscript collections and to keep it up to date (UNESCO, 1960)

In a paper addressed to the IFLA Section of National and University Libraries (Rome 1964), Humphreys attempted a further assessment of the role of national libraries based on the experience of the British Museum, the Lenin Library in Moscow, the Bibliothèque Nationale and the Library of Congress. He chose to divide the national library activities into three categories from the 'inessential to the desirable and lastly to the essential.' In agreement with the Vienna symposium, Humphreys identified four activities as 'essential':

- collecting legal deposit publications;

- international exchange of publications;

- creation of a national bibliography;

- keeping catalogues up to date. (Humphreys, 1966)

From these statements, it is clear that the priority was put on the consolidation of national bibliographic services. The national library was seen as best qualified to undertake the production of a current national bibliography and the training of bibliographers because it was often the only institution of the country to combine all three conditions: stock, staff and catalogues (Humphreys, 1988).

The development of research on an international level, combined with the economic recession of the mid-70s, has incited libraries to cooperate internationally in order to achieve greater efficiency in the access and exchange of bibliographic records, access to publications and exchange of professional skills. This trend towards thinking in international terms was supported by IFLA with the instigation of programmes such as Universal Bibliographic Control (UBC), Universal Availability of Publications (UAP), and Preservation and Conservation (PAC), the latter currently being hosted by the BNF.

On its part, UNESCO (1974) launched, in the early 1970s, a major information programme, National Information Systems (NATIS), to encourage each country to develop its information infrastructures so as to fulfil potential and real information needs of all categories of users, including those in social sciences. It was regarded by UNESCO as a complementary programme to UNISIST (World Information System for Science and Technology) which had been designed to be a world information network for science and technology only. Eventually 
the two programmes were combined into a new Division, the General Information Programme (PGI).

One of the first requirements spelt out by the authors of NATIS was the formulation of: a national policy, reflecting the needs of all sectors of the community, and of the national community as a whole [...] to guide the establishment of national information plan, whose elements should be fully incorporated in the national development plans (UNESCO, 1974, p. 12).

From its very early days, the European Commission recognised the growing economic and political importance of information, but until the early 1980s, the Commission considered the information sector quite separate from the library sector. The policies instigated during those years aimed to reach end-users directly, without the interference of librarians. The Plan of Action for Libraries in the EC, established in 1987 (Europa Web site, 16 September, 1996), marked a major change. Officials in DGXIII ${ }^{4}$ started to look to libraries to provide an important customer base for electronic information services just as they do for printed publications. This new policy gave birth to a series of projects funded by the Commission, such as CD-BIB (National Libraries Project on CD-ROM) with the objective of economising in library cataloguing through an improved interchange of bibliographic records between European national bibliographic agencies irrespective of different national MARC formats. CoBRA, one of the latest programmes operating under the 'Fourth Framework Programme', (Computerised Bibliographic Record Actions) is the concerted action of seven European national libraries ${ }^{5}$ which aim to promote initiatives and actions in the field of national bibliographic services at a European level (Zilhardt, 1996).

In this context of European interlibrary cooperation, a possible new role for national libraries has emerged, that is to promote the benefits of such programmes and to encourage coherence in their implementation in order to develop an EU perspective (Brophy, 1995). The British Library, through its International Office, made information available to libraries and others, advertising calls for proposals for European Commission Research programmes. However, some countries such as France have set up special agencies to perform these functions. ${ }^{6}$

In a UNESCO-sponsored study on the role of national libraries in the new information environment, Cornish (1991) comments on how new technical developments challenge every aspect of the traditional role of national libraries. On one hand, on-line bibliographic databases, such as OPACs and union catalogues, enable more people to know of the national collections and utilise them. It can be then assumed that the national library becomes the centre for cooperative collection development and cataloguing. At the same time, increased access to bibliographic data may well increase demand on the resources of the national library. On the other hand, this technology may enable users to have direct access to documents without the need to resort to the national library.

Furthermore, existing practices in legal deposit and bibliographic control may not be applicable to published electronic documents. In an article on the future of the legal deposit in

\footnotetext{
${ }^{4}$ Directorate General XIII is equivalent to a ministry or government department within the European Commission. It is involved in matter of information policy, communications, information industries and innovation.

${ }^{5}$ United Kingdom, France, Netherlands, Switzerland, Finland, Germany, Portugal.

${ }^{6}$ Comité français de pilotage du plan d'action pour les bibliothèques (CFPPA), 8 rue du Scribe, Paris.
} 
France, Olivier de Solan (1995) examines the distinction between primary and secondary documents in the context of computerised information. In this context, primary documents are considered to be the original expression of an intellectual output in a given format while documents, such as application and navigation software, tools to access that primary document, are considered secondary documents. In absolute terms, secondary document are the result of a technique, not a product of the mind and therefore not subject to legal deposit. Primary documents are therefore the only documents that a national library should consider to retain because they reflect the exchange of ideas at any given time in the history of human activity. In practical terms, it means that the national library must find ways to isolate primary documents and present them to the user via a standardised set of secondary documents.

In this new context, de Solan recommends that national libraries should think to share with other institutions certain conventional responsibilities such as the collection, storage and preservation of the national heritage. Instead, national libraries should adopt a more proactive role in ensuring that the national bibliographic heritage is accessible to all. A national library should be able to:

- provide national leadership in library and information affairs;

- be the prime mover in library developments;

- provide a national information system to facilitate economic and social development at both national and personal levels;

- make its collection nationally available;

- provide the focus for an international document supply system;

- provide a national referral service;

- provide a central co-ordinating point for research in library and information science.

The latest major international conference on national libraries (Taipei, April 1993), has given professionals the opportunity to expand on Cornish's considerations with the presentation by Etheredge (1994) of the 'virtual library' established in Switzerland, linking electronic material through hypertext images. This is a new approach to national library provision, based on a distributed system of institutions, each responsible for designated subject areas and strongly networked together. In any case, it seems that international networking is having a significant effect on the thinking of national libraries in those countries which are already heavily networked. Griffiths (1993) argues that the key roles now for a national library are ensuring the development of national network infrastructure suitable for library purposes, enabling a coordinated collection development, and incorporating a repertory to all distributed on-line catalogues of libraries throughout the country.

For some librarians, it is not only a question of defining what a national library is, but of justifying its very existence:

The first task should not to establish or even maintain a national library [...] but to decide precisely what library and information functions need to be carried out at national level (Line, 1990, p.29).

Line's statement represents a fairly accurate reflection of contemporary librarians' concerns with the present role of national libraries (Sauvageau, 1991; Wainwright, 1993; Wuest, 1993), particularly in the Anglo-Saxon world, while others (Humphreys, 1988; Melot, 1996) regret this utilitarian approach. Instead they see the national library as a powerful symbol of its nation, in terms of it vast recorded cultural and intellectual heritage. This view prevails 
strongly among the public. It confers on the national library a permanent status which has been recognised by those countries which have recently invested huge sums in the construction of new building for their national library such as the United Kingdom, China, Denmark, Algeria, Taiwan and France.

\section{Genesis of a major project}

The project of the Bibliothèque Nationale de France was launched soon after the French President François Mitterrand was re-elected to a second term of office in Spring 1988. During his first mandate, Mitterrand gave the Ministère de la Culture the means to innovate a cultural policy which was part of a wider concern, central to the socialist ideal, that is the democratisation of knowledge. The Bibliothèque Nationale, which had been under the administration of the Ministère de la Culture since 1975, benefited from these measures by having its budget increased substantially. However, it seemed that the BN had reached the limits of its original site: it could not accommodate any more materials or visitors, and was losing its place as a major international research library.

The impetus for action started with the publication of a critical report compiled in 1987 by Francis Beck, a former administrative Director at the Ministère de la Culture. ${ }^{7}$ His recommendations can be summarised as follows:

- legal deposit must be reformed to allow an 'intelligent' selection of relevant documents;

- the deficiencies of universities libraries, especially in the Paris area must be redressed, if reforms proposed for the BN are to succeed.

As for the BN itself, he suggested:

- the BN must centre its activities on printed and audio-visual documents only and move other material to specialised institutions, such as museums;

- the decentralisation in a separate building outside Paris or in the provinces of all activities not connected with the communication of collections, i.e. legal deposit processing, foreign acquisitions, conservation, and all bibliographic functions.

Although Francis Beck's recommendations were perceived as being too radical, the idea of building an extension to the BN was supported by its 'Administrateur Général', Emmanuel Le Roy Ladurie.

The Ministre de la Culture, François Leotard, announced on 13 April 1988, the reorganisation of the Bibliothèque Nationale, together with the project for the construction, in Paris or in its immediate vicinity, of a 'Bibliothèque Nationale 2' to accommodate all books published after 1990. At the same time, the Minister announced a development plan for bibliographic information and a plan for the preservation of the Bibliothèque's collections; his preferred option being to redirect the focus of the $\mathrm{BN}$ activities towards books and printed material.

However, on 14 July 1988, during the television interview given each year by the President on Bastille day, François Mitterrand announced the launching of the last of his grand projects, namely the construction of a very large and modern library of a wholly new type. This declaration was a total surprise to all, even to those working at the Ministère de la Culture, including Le Roy Ladurie. However, it seems that the idea of a futuristic networked library

\footnotetext{
${ }^{7}$ Although the report was not published, a fairly comprehensive summary can be found in Le Monde, 7 Decembre, 1987.
} 
had already been put forward by one of Mitterrand's closest advisors, Jacques Attali (1995). The communiqué following the presidential speech emphasised that the State was ready to engage heavily in financial provisions (Gattegno, 1992). As the nature of the future library remained unclear, the project came to be known as the TGB for 'Très Grande Bibliothèque' an acronym coined by a journalist in an article titled: Quelle très grande bibliothèque? ${ }^{8}$ (Nora, 1989).

A month after the President's speech, a feasibility study was entrusted to Patrice Cahart, Director of the National Mint, and Michel Melot, Director of the Bibliothèque Publique d'Information at the Pompidou Centre in Paris. In late November they submitted their study to the Prime Minister (Cahart \& Melot, 1989). In the course of their investigations, they had analysed the collections and the services of the BN, evaluated advanced information technologies for libraries, examined various premises in Paris and the immediate vicinity, and estimated the cost for building the TGB. Their report included recommendations for a large reading room providing 2,000 places, with free public access to 500,000 volumes, and for a separate reading room providing over 1,600 seats for researchers. The authors were recommending a six-fold increase in the capacity of the Bibliothèque Nationale. They maintained that, as the modern branch of the national library, the future library should be able to start with a strong initial collection without having to reach gigantic proportions.

Acquisition policies should be expanded and collections of printed material published after 1945 transferred to the new site (approx. 3 million volumes). The report also contained proposals on audio-visual material, new technologies and remote access. Several sites were suggested, both in Paris and the suburbs, and even in the provinces. Finally they suggested the re-titling of the future library as the 'Bibliothèque de France'.

The press and public had been slow to react to Mitterrand's speech, but the publication of the Cahart and Melot proposals started an open debate in the specialist press which was readily taken up by national newspapers. Although no particular problems were raised by the final selection of the site on the Quai de Tolbiac in the east end of Paris, the chronological division of the BN's collections was a different matter (Nora, 1989; Julliard, 1989). The idea of transferring only part of the BN collection of printed material sparked a controversy, which remained unresolved until August 1989 when Jack Lang, the new Ministre de la Culture, announced that the division of the collection was to be abandoned in favour of transferring the entire collection of printed material and periodicals to the new building (approx. 11 million books).

The overall responsibility for the project was handed over to the Ministère des Travaux Publics $^{9}$. As early as 1988, it emerged from the correspondence exchanged between François Mitterrand and the various officials in charge of the project (Lettre de François Mitterrand à Michel Rocard, Aug. 1988 in: Gattegno, 1992) that the date for the inauguration of the Tolbiac building would be set for Spring 1995, in order to coincide with the end of the President's second term in office. For Emile Biasini, Secrétaire d'Etat aux Grands Travaux ${ }^{10}$, all planning decisions had to be made with that date in mind (Biasini, 1990).

A pre-planning group, the Association pour la Bibliothèque de France (APBF), chaired by the novelist and journalist Dominique Jamet, was appointed by François Mitterrand in early 1989.

\footnotetext{
${ }^{8}$ What kind of large library?

${ }^{9}$ Ministry of Public Works

${ }^{10}$ Secretary of State for Public Works
} 
The APBF drew up a programme of ideas aimed to brief the architects taking part in an international architectural contest (Ministère de la Culture et al, 1989). This programme followed to a large extent the propositions enunciated by Cahart and Melot; its purpose was to inspire the imagination of the candidates in the creation of a large library building at Tolbiac, and also of a conservation and storage centre at Marne-la-Vallée, $30 \mathrm{~km}$ east of Paris. In July 1989, an international jury, chaired by the American architect I.M. Pei, ${ }^{11}$ selected four projects, with particular recommendation given to the one submitted by Dominique Perrault. This was President Mitterrand's final choice.

In October 1989, the APBF was granted a public status and consequently re-named the 'Etablissement public pour la Bibliothèque de France' (EPBF). This body was made responsible for the planning schedule for the future library, for the proposal of budget, for the construction work on the Tolbiac site, and the organisation of the contents of the building, in consultation with the $\mathrm{BN}$. This gave new impetus to the project, and in 1990 the Bibliothèque Nationale began the major task of stocktaking the collections and computerising all its catalogues (Bibliothèque de France, 1990). Foundation works on the Tolbiac site started in December 1990.

At the 1993 legislative elections, Mitterrand lost his majority in the Assemblée Nationale and a government led by the opposition leader was established. In an attempt at rationalisation, Jacques Toubon, the Ministre de la Culture of the new coalition government, proposed that the 'Bibliothèque Nationale and the Bibliothèque de France' should merge into a single institution. The Bibliothèque Nationale de France (BNF) was established by decree on 3 January 1994. The historian Jean Favier, former Director of the Archives de France, was designated as its President. Philippe Belaval, a senior civil servant, who had been commissioned to study the feasibility of the merger between the two institutions, was appointed its Director.

The various elements of the mission of the BNF outlined in the decree can be summarised as follows:

- to collect, catalogue, conserve, and enhance the national cultural heritage; to that end, it must act as a legal depository for: all printed documents, manuscripts, audio-visual material, coins and medals, maps and plans, musical scores and electronic documents;

- to compile and distribute a national bibliography;

- to participate to international undertakings in the field of bibliographic activities;

- to ensure the access of collections to the largest possible public;

- to cooperate with other libraries and research centres in France and in Europe in the creation of a network of documentation services;

- to take part in the pooling of French library resources in accordance with government policies;

- to work towards remote consultation of documents by using the latest technology (Ministère de la Culture et de la francophonie, 1994).

Since its establishment, the BNF has continued the policies instigated by the EPBF in an effort to implement the programme that President Mitterrand had set up in his 1988 speech. New elections brought an opposition majority at the Assemblée Nationale in 1993 and a President from the opposition in 1995. The project was not abandoned because four billion

\footnotetext{
${ }^{11}$ I.M.Pei had previously been responsible for the construction of the glass pyramid in The Louvre courtyard.
} 
Francs had been already spent, but soon the budget of the Ministère de la Culture was reduced by $5 \%$, as part of an austerity policy conducted in an effort to qualify for the European common currency project.

The Tolbiac building was completed in time for the official opening by François Mitterrand on March 30th 1995, as planned. Since then, the project teams have opted for a public opening in two stages: the upper level library was inaugurated by President Jacques Chirac on 17 December 1996. By then it had been decided to name the building after its instigator, François Mitterrand. The research library on the lower level opened 2 years later, as planned, on 9th October1998.

\section{The French library scene: background study and current players}

President Mitterrand's wish, that the future library should be 'connected with all major university and research libraries in Europe', has been expressed in the second article of the decree of 3 January 1994 (Ministère de la Culture, 4 Jan. 1994, p.149) which stipulated the second mission of the Bibliothèque de France as:

- to ensure the access of collections to the largest public possible.

To that end:

- it must cooperate with other libraries and research centres in France and in Europe to the creation of a network of documentation services;

- it must take part to the pooling of French library resources in accordance with government policies;

- it works towards remote consultation of documents by using the latest technology; ${ }^{12}$

Since 1975, responsibility for libraries has been split between the Direction du Livre et de la Lecture (DLL) at the Ministère de la Culture and the 'Direction des Bibliothèques, des Musées et de l'Information Scientifique et Technique' (DBMIST) at the Ministère de l'enseignement supérieur. The Conseil Supérieur des Bibliothèques (CBS), created in 1989, is a consultative inter-ministry council charged with assessing library provision and with putting forward recommendations for their development and their organisation. Evaluations and propositions are published in an annual report which constitutes to date the best public source of information on French library issues (Conseil Supérieur des Bibliothèques, 1991 to 1995).

\section{The French library scene: public libraries}

The decentralisation laws implemented by the government in 1982/83 significantly increased the local authorities' impact on cultural policy ${ }^{13}$, with the local library being often the most visible symbol of this phenomenon. However, it is important to emphasise that a local authority is under no legal obligation to provide a library service to its residents.

The project of the BNF was announced towards the end of a successful government programme for the expansion of public library services ${ }^{14}$ (Bertrand, 1992). The government

\footnotetext{
${ }^{12}$ Author's translation.

${ }^{13}$ Reforms which have devolved central control to local authorities. There are now three levels of administrative and political units in metropolitan France: 22 régions, 95 départements and 36,000 communes.

${ }^{14}$ For example, between 1971 and 1982, the floor area of libraries doubled from 350,000 to 660,000 $\mathrm{m}^{2}$, it doubled again from 1982 to 1988 (DLL, 1994).
} 
had created the Bibliothèques Départementales de Prêt (BDP) in 1945 to reach out a vast rural population deprived of library provision (Direction du Livre et de la Lecture, 1995).

Providing facilities for public reading had become the responsibility of the Bibliothèques Municipales (BM), within the framework of the 36,000 communes, the smallest political and administrative unit in France. The BM had previously offered little in the way of reference services and even less in the way of community services. Traditionally they had been geared towards conservation and service to researchers on account of their rich collections of manuscripts and rare books, most of them acquired from the confiscation during the Revolution and the 1905 separation of Church and State (Comte, 1977, p.147).

The DLL has identified three categories of public libraries which may play a potential role in the setting up of a regional library network. No hierarchical structure is planned to support that role. It is also assumed that, by becoming a regional leader in library services, the assets of those libraries can potentially be used on a national level and therefore complement the BNF. These libraries are:

- the 19 municipal libraries which are the recipient of legal deposit items from local printers and publishers. Processing, housing and preserving costs of deposited items are covered by the BNF.

- the 45 listed libraries are those which house a particularly precious collection of ancient books or manuscripts. Here again, the state supplies funds for the conservation of these items.

- the 32 'Bibliothèques Municipales à Vocation Régionale' (BMVR), are libraries with an adult collection exceeding 250,000 volumes, located in towns of over 100000 inhabitants. Government aid is of a different nature here: it targets library buildings and equipment to enhance the use of collections.

Paris offers a network of 56 public libraries, including 11 for young people and 6 specialised libraries (Netzer, 1989, p. 44). The network operates with one technical service which deals with the purchasing and processing of most documents. The 'Bibliothèque publique d'information' (BPI), opened in 1977 in the famous 'Pompidou Centre', offers to everyone, for reference use only, a multi-media collection of documents on current affairs and general information updated regularly. The catalogue is accessible on Minitel, and distant users may correspond by E-mail (Lieber, 1992). The BPI has met with great success with 13,000 visitors daily, constituted mainly of students who do not hesitate to queue outside for several hours as the facilities of university libraries in Paris are far from being satisfactory. The Mediathèque de la Villette, in the north of Paris, was established in 1986. It holds all the scientific, technical and industrial information available today within a certain degree of specialisation. It includes a public media library, which offers a general information service, a specialised media library for researchers, and an area for children.

When the programme of administrative decentralisation for public libraries was implemented in 1986, the administration of BMs and BCPs was transferred from the DLL to the local authorities, the BMs to the communes, the BCPs to the départements. However, this transfer of responsibility was not supplemented by a legislative programme to clarify the obligations of local authorities in terms of cooperation between the BMs and the BCPs. The initiative to organise such a complex structure has come from the libraries themselves and from the associations which represent them. It has resulted in the creation of 'Agences de Cooperation', operating at the department or région level. Most of them have taken on the form of associative structures and decide upon their priorities in accordance with their 
regional needs. However, their actions may be limited and short-lived because they do not enjoy any institutional support (Bertrand, 1994). Since 1985, under the instigation of the DLL, these agencies have gathered forces in the FFCB (Federation française de cooperation des bibliothèques).

\section{The French library scene: academic and research libraries}

Academic libraries have also been subjected to reforms which have resulted in the decentralisation of state control.

Between 1970 and 1988, the student population grew by 56\%. Resources did not match these changes, and the degradation of university libraries became a national concern. In 1988, a survey of the situation was commissioned from A. Miquel, a former Administrateur Général at the BN. It seems that findings and recommendations enunciated in Miquel's report may have given the impetus to a dynamic government policy as government funding for academic libraries increased by $131 \%$ from 1987 to 1990 . However, the latest report on university libraries by the CSB warns that, in real terms, the situation in 1995 is worse than in 1989.

The way in which French universities have evolved has allowed the development of several types of academic libraries operating within a single university. The inter-university libraries serve the needs of more than one institution in areas where there is a high concentration of universities (e.g. Marseille/Aix-en-Provence, Toulouse). Funding comes from the different universities and as it is difficult to identify the institutional origin of the 'clients' using a particular library, these inter-university libraries appear under-funded. In the Paris area in particular, the situation has become unmanageable. There are nine inter-university libraries servicing 18 academic institutions, with no defined allocation. As a remedy, the CSB recommends that these libraries should be removed from the university structure; become autonomous public institutions with the primary mission to serve research; and be funded directly by the state and local authorities.

The 4,000 research teams working within French universities have the additional resource of research libraries. Some of these libraries have an international reputation for the excellence of their collections. A further group of specialised and research libraries includes libraries of research institutes, 'Grandes Ecoles ${ }^{\text {, }}$, ministries etc., aimed particularly at specialised researchers in the discipline covered by their stock, offering them collections as complete as possible in their specific field of research, however narrow. A number of these libraries have become documentation centres as well, and have acquired a status of unchallenged authority in their field. This is not the result of a particular policy, but merely of the fact that such centres have been more enterprising (Meyriat, 1986).

\section{The French library scene: inter-lending and document supply in France}

Due to the absence of appropriate legislation and to the fact that libraries are administered by different government ministries, the French inter-lending and document supply system is largely decentralised with a strong tradition of freedom to choose which library will be approached for a loan and, equally, freedom to decline to participate in interlibrary lending (Cornish, 1990). There is, at this stage, no union catalogue of French monographs, and the BNF lending centre for French monographic publications was dismantled in 1996. Requests

\footnotetext{
${ }^{15}$ Prestigious specialised schools of university level with competitive entrance and exit examinations.
} 
for periodicals (French or foreign), are handled by the Institut National de l'Information Scientifique et Technique (INIST), the document supply service for the 'Centre national de la recherche scientifique' (CNRS), a state institution with the mission to coordinate scientific research of all kinds.

\section{The legacy of the Bibliothèque Nationale and the activities of the Bibliothèque Nationale de France}

Before the identity of the Bibliothèque de France was established, the 'Association pour la Bibliothèque de France' agreed that the future library should ensure the 'continuation and modernisation of the Bibliothèque Nationale' (Ministère de la Culture et al, 1989, p.3). This requires that any review of the BNF should take account of the historic development of the functions of the $\mathrm{BN}$, as well as those which were prompted by more recent legislation.

The decree of 4 January 1994, ratifying the creation of the Bibliothèque Nationale de France, stipulates that the new institution is to continue to be the agency for the national bibliography with the corollary of processing, cataloguing, communicating, preserving the collection acquired by legal deposit. This mission leads to further functions: the computerisation of the catalogues, the marketing of bibliographic products, and the preservation of its collections.

A legal deposit system was established in France in 1537 by King Francis I who decreed that one copy of all books printed in his kingdom should be sent to the Royal Library before being put for sale. By the middle of the 19th century, it became evident that the law had to take into consideration the new information carriers. Hence the legislation of 1881 which extended the application of legal deposit to engravings, photographs and audio-visual material. However, it was not until 1938 that measures concerning audio-visual media came into practice. The system was drastically reformed in 1925 with the introduction of deposit obligations for both printers and publishers. The publisher had to submit a copy directly to the $\mathrm{BN}$, and the printer to a designated local library. At the time of the announcement of the 'Très Grande Bibliothèque', legal deposit in France was ruled by the law of 21 June 1943 and ten subsequent decrees. No less than seven copies of printed monographs had to be deposited. With the view to clarifying legal obligations in regard to non-printed material, and to simplify the existing mode of operation, a new law on legal deposit was published on 20 June 1992.

The 31 December 1993 Decree (Ministère de la Culture, 1993) stipulates the operational aspects in great details. There are to be three depository institutions according to the format of publication:

- The Bibliothèque Nationale de France with:

- 5 or 6 copies of all printed works ( 4 from the publisher, 1 from the printer or 2 if the printer operates in the Parisian area); ${ }^{16}$

- 2 copies of electronic documents as mentioned in Art. 1

- 2 copies of sound recordings of all kinds;

- 2 copies of video recordings with no fixed chemical video medium.

- The Centre National de la Cinematographie (CNC) with:

- 1 copy of video recording on photochemical media;

- 1 copy of each film produced by a French firm.

- The Institut National de l'Audiovisuel (INA) with:

\footnotetext{
${ }^{16}$ Outside the Paris area (Ile de France), the printer is under obligation to deposit one copy with a designated copyright municipal library. There are 19 such libraries across France.
} 
- 1 copy of all sound recordings;

- audio-visual material broadcast on radio or television, with the provision to sample and apply a selection.

Without introducing radical changes, the new legislation has attempted to adapt French legal deposit to new technologies by targeting all documents whatever their means of production and distribution (Hoare, 1996). The paramount requirement for legal deposit is the availability of a document to the public. The practice of redistributing one copy from the publisher at a local level implies that collections held in each of the 19 associated municipal libraries will reflect the local publishing activity and, therefore, will allow the compilation of regional bibliographies.

As the new Tolbiac library opens, books, periodicals and audio-visual material will be transferred there. The remainder of the collections will be relocated in the Richelieu building. A new unit has been constructed at Marne-la-Vallée to serve as warehouse for one copy of each book, periodical and audio-visual production, for the purpose of absolute conservation, that is to be neither circulated nor loaned. ${ }^{17}$

The printed material department holds over 10 million works collected over five centuries. It includes all French and foreign publications acquired through legal deposit, purchase, gifts of exchanges and all French periodicals acquired until 1959. Periodicals were housed in the new periodicals department after that point. The periodicals department has grown steadily, taking in all journals and newspapers published in France (32,000 current titles), as well as a selection of foreign titles, mainly in the humanities and social sciences, from nearly 150 countries.

Since 1990, an accelerated acquisition programme has been implemented to establish open access collections in the Tolbiac building and, in accordance with the encyclopaedic and more international perspective of President Mitterrand's plan, to bring in additional material in fields that were not adequately represented in the BN collections, such as sciences, technology, medicine and audio-visual material. Certain criteria of selection have been set up by a committee of academics and researchers of all disciplines (La Lettre d'information, 1992). For this reason, the teams in charge of selection for the scientific collections have opted for reference materials which aim to inform a scientific user on the state of recorded knowledge in a discipline close to his/her own and to allow an appreciation of the debates currently present in other scientific subjects. Popular scientific works will be represented only from accredited authors.

The origins of the sound archives and audio-visual department go back to 1911 with the creation then of the 'Archives de la parole', the first sound library to be established in France. In 1977, it was incorporated into the BN, and has been since the legal depository for video recordings and multi-media productions. The development of the collection of audio-visual material is linked to the encyclopaedic mission of the BNF. This point was strongly supported in the Cahart and Melot report together with the recommendation that the future library should act as the depository of legal deposit material. The 1992 legislation also reinstated the INA and CNC as depository institutions for audio-visual items.

\footnotetext{
${ }^{17}$ This practice might be under review in the years to come, once conservation priorities are reassessed. (Information supplied by Jerome Belmon, DLL)
} 
The French national library has not been granted the means to develop a lending centre comparable to the British Library Document Supply Centre at Boston Spa. Until its dismantling in the Autumn of 1996, the BNF lending centre relied on a collection constituted of copies from the legal deposit stock (in practice only since 1980), of duplicated microfilms and, since 1986, used services provided by OCLC (Blasselle, 1993).

\section{The programmes of the Bibliothèque Nationale de France}

The French research community has at its disposal a rich resource of material, but the absence of a centralised coordinating authority means that these resources may be under-used. This is the reason why the planning of the Bibliothèque Nationale de France includes a process of network integration with the implementation of three major programmes:

- the 'pôles associés' or affiliated institutions;

- the Catalogue Collectif de France (CCF) or union catalogue;

- creation of digitised remote access collections.

To that end, planners at the BNF have designated four types of institutions to share the responsibilities of setting up such a policy. They are:

- the CADISTs ('Centres de l'Acquisition et de la Diffusion de l'Information Scientifique et Technique') - university libraries designated to cooperate in acquisitions and act as major suppliers of documents in particular research disciplines

- the 19 municipal libraries which are depository of legal deposit by local printers and publishers.

- the 45 listed libraries with collection of ancient books or manuscripts

- the 32 'Bibliothèques municipales à vocation régionale'.

From this pool of library resources, the Bibliothèque de France has pursued a further selection by signing agreements with certain libraries and documentation centres whose collections are complementary to its own. The BNF grants them subsidies to complete acquisitions in their specific domain and to develop the necessary technology towards computerised inter-library loan. In return, the associated institutions agree to process and lend the collections constituted under their contract. At present, 16 institutions, so-called 'pôles associés' (associated institutions) have signed agreements with the Bibliothèque de France. Among these affiliated institutions, only three (Strasbourg, Lyon and Poitiers) belong to all four categories of libraries mentioned above.

The second major programme aims to produce an union catalogue made up of the most useful documents to research to be found in French libraries and documentation centres and of course of the BNF's catalogue (over 7 million entries when it is completed). To complement the existing tools of cooperation mentioned earlier (CCN, Pancatalogue, E.mail system for interlibrary loans), an additional facility is being created, namely a computerised directory of libraries taking part in the union catalogue, the $\mathrm{RNBCD}^{6}$. The CCF is a data-base of catalogues. It will be used as a data location tool, to supply researchers with an integrated search system enabling them to identify, locate and request the transmission or the reproduction of any document, wherever it may be, in a single operation. Meanwhile the $\mathrm{BNF}$ is co-financing a retrospective computerised catalogue-conversion programme, which is to run over several years, involving 50 municipal libraries and 30 university libraries. The

\footnotetext{
${ }^{6}$ Répertoire National des Bibliothèques et Centres de Documentation.
} 
CCF will eventually provide access to 13 million bibliographic entries for documents of all types.

A third project is to set up remote-access digitised collections, which are currently being processed, involving printed material (100,000 volumes) when the new site opens, as well as the collection of images (300,000 images).These collections, initially accessible only at the BNF's premises, will eventually reach anyone who will be connected to the network. The digitised collections are drawn essentially from the BNF's collections, mainly using microform reproductions as source documents. However, a large number of external institutions are contributing to the programme.

\section{The Bibliothèque Nationale de France at Tolbiac}

The candidates taking part in the architectural contest launched by the APBF worked on a brief of about 37 pages representing only a collection of preliminary ideas outlining basic requirements in terms of the library's missions, the environment, and the library's functions in an electronic age (Ministère de la Culture et al, 1989). It also stipulated the need to create two types of research facilities, one for the specialised researchers and one for the general public. Figures of expected visitors ( 5 to 6 million per year) and maximal stock ( 7 million documents) gave an indication of the required size of the building, but, in order to attract the public to the pursuit of knowledge, emphasis was put on appeal and conviviality. While the architecture must exhibit the 'treasures' of the national cultural heritage, it must not be intimidating to the general public. Finally, according to the brief, the building must convey the mythical duality of libraries i.e. treasure/attraction while reflecting their functional duality, i.e. conservation/communication.

The library occupies the former site of disused railway yards east of the Gare d'Austerlitz alongside the left bank of the river Seine, between the Bercy and Tolbiac bridges, in the $13^{\text {th }}$ arrondissement. This site is part of a wider area of abandoned warehouses and factories. The City of Paris donated 7 hectares to the state for the purpose of building the library as part of a planned renovation programme of this run down part of Paris. In addition to public buses and underground services, a new express underground service METEOR is under construction to link the left bank of the Seine to the railway stations on the right bank with a stop near the Richelieu site. Public car parks are provided underground.

Dominique Perrault's design for the building is schematically based on a hollow rectangular block supporting a tower in the shape of an open book at each corner. The first impression is that of a rectangular structure without walls, with four huge, 79 metre-high towers at each corner. The desired effect of the tower's transparency, is achieved by the application of a special glass sheathing over the existing window panes. The central cavity (30m deep) is occupied by a sunken garden made of tall mature trees specially imported from Normandy.

The base area forms a single esplanade of six hectares surrounded by wide flights of stairs giving access from the Seine embankment and from the West and East. It is entirely floored (steps included) with ipe, a timber from the Amazon rain forest. It is aimed to serve as a public square as well. It is planned to build a footbridge linking the library to the other bank of the river. A 32 hectares concrete slab will eventually cover the whole railway track area on the north-west side of the building.

Inside the base, the library will function on two levels: 
- the upper level occupying the whole area directly beneath the esplanade, including the cavity created by the steps; it accommodates the 'public research library' aimed to give a reference service of academic level to the general public.

- the lower level built underground ( $7 \mathrm{~m}$ beneath the river bed) and protected on the outside by a moulded concrete wall; it houses the 'specialised research library' for the restricted use of accredited researchers.

In both libraries, reading rooms are positioned alongside the sunken garden, with workshops, stacks and service areas encircling them on the outer side. Access to the specialised research library is subject to an interview with a librarian in an enclosed area adjacent to the reception halls where applicants may be able to consult on-line catalogues.

The 1,700-seat public research library offers open access to a collection at the academic level of encyclopaedic reference material. Facilities planned are as follows:

- a 180 seat press reading room offering 500 current periodicals and 5,000 topical monographs

- a 80 seat bibliographic service area providing 5,000 volumes and 100 periodical titles of catalogue and bibliographical material. It is also here that encyclopaedic reference material will be kept

- special equipped area for visually impaired users

- 75 audio-visual stations are scattered among the four departments

- four reading rooms offering open access material, organised in four thematic departments and catalogued on a CD-ROM.

These departments house the following collections:

- philosophy, history, humanities and social sciences, with 275 seats on two levels, with 75,000 monographs and 350 periodicals. This section will also accommodate facilities to view audio-visual documents, such as documentaries and current awareness information on contemporary France;

- political, economic and legal sciences, also with 275 seats on two levels, and a large proportion of the collection (70,000 monographs and 600 periodicals) constituted of reference documents: statistics, reports, directories and official publications;

- science and technology, with 199 seats, with 55, 000 monographs and 350 periodicals;

- art and literature, with 556 seats, in the largest reading room with 140,000 monographs and 600 periodicals covering French as well as foreign literature.

The specialised research library, situated on the lower level, is to be used only by those able to justify their need to consult the library's heritage collections. Two open-plan reading halls run along the two sides of the garden, with issue desks positioned perpendicularly at regular intervals. Researchers will be provided with 2,000 seats, of which 1,600 may be reserved in advance. Over 300 search stations will be available throughout the whole reading area. Mezzanines floors are composed of carrels where readers will be able to keep their documents at their reserved place up to a period of two weeks. 45 viewing and listening stations are scattered on the mezzanine area to allow the consultation of audio-visual and microfilm materials. Both reading rooms and collections are organised in the same four thematic departments:

- philosophy, history, humanities and social sciences with 494 seats;

- political, economic and legal sciences with 321 seats;

- art and literature with 411 seats.

- science and technology with 199 seats; 
In addition, each department will provide open access to a collection of 400,000 titles (monographs and periodicals), also divided into the set disciplines. Readers, but not documents, will be allowed to move from one department to an other. Researchers will also have at their disposal:

- a 200 seat bibliographic services area offering, on-line searching stations and as many as 50,000 printed catalogues and bibliographies.

- a 316 seat audio-visual centre giving access to audio-visual and multimedia materials collected through legal deposit, including broadcast materials from French radio and television programmes

- original documents which can be consulted on request in designated cubicles and projection rooms

- 30,000 monographs and 800 periodical titles available on open access.

- a 55 seat 'Rare Books' consultation room located between the two library levels, or the 'Réserve' situated above the main reading room. Access will be granted only to accredited researchers.

- a small area of 56 seats, the 'salle de documentation' devoted to the study of the history of the book publishing, the techniques of books manufacturing and reading practices.

As mentioned earlier, the totality of printed and audio-visual collections will be housed at the Marne-la-Vallée and the Tolbiac sites. The warehouse at Marne-la-Vallée offers $73 \mathrm{~km}$ of shelving space increasing eventually to $321 \mathrm{~km}$ to house legal deposit copies designated for conservation only, i.e. never to be circulated. The Tolbiac building offers a capacity of 395 $\mathrm{km}$ of shelving space compared to $147 \mathrm{~km}$ presently at the Richelieu site.

At Tolbiac, conservation workshops are engaged in general maintenance and minor repair only, but the centre at Marne-la-Vallée will be housing workshops set up for the purpose of preserving material on a near industrial basis. Its de-acidification facilities ultimately aim to treat about 300,000 volumes each year. This unit will also accommodate workshops specialising in the conservation of audio-visual material, through digitisation in particular.

A new computer system will replace the previous system, integrating all of the Bibliothèque Nationale de France's activities. The new system will provide an internal communications network for readers and library staff, as well as external communications through the INTERNET and input to other networks, such as the Catalogue Collectif de France.

On opening, the Bibliothèque aimed to provide encyclopaedic reference facilities covering some 100,000 volumes of digitised text and 300,000 of images, to be consulted on site. Two methods of consultation are available:

- the 'VDU-assisted reading stations' will allow easy browsing through the different parts of the book via its table of contents;

- the computerised reading stations or 'Poste de Lecture Assistée par Ordinateur' (PLAO) will, in addition, provide word-processing facilities and enable users to create their own customised search files; these reading stations will be located on the lower garden level for the exclusive use of researchers. On opening, the number of PLAO will be limited to 12 only.

At the same time as the unveiling of a model to the public, the architect published a book (Perrault, 1989) explaining the various symbolic elements of his building. The four towers 
are designed to exhibit the 'trésors' of the French cultural heritage and must serve as a prestigious landmark for the east of Paris, counterbalancing the architectural achievements of the Défense area, in the west. The towers must convey the significance of the material they contain and inspire respect, but because they are in the shape of an open book, they convey the availability of this treasures, by inviting the public to explore. The transparency of the towers emphasise even more the accessibility of the French cultural heritage. At the same time, the use of shutters (protecting the stacks) conveys the idea that these 'trésors' are sheltered and therefore secure. At office levels, transparency combined with the possibility of opening the shutters aims to display office life; it allows to show the purpose of the building. Transparency reflects the architect's new approach to institutional architecture.

From being directed at the aesthetic of the building, criticism focused on functional issues. A former Administrateur Général of the BN, George Le Rider, instigated an open letter to Président Mitterrand, signed by more than 700 figures in the academic world, which ended with the remark:

"It is the duty of the architect to make a functional building beautiful, not to adopt exactly the reverse procedure” (Le Monde, 10 Oct. 1991).

A few days later Le Monde (14 Nov.) gave the architect the opportunity to reply to Le Rider's reproach:

"The fundamental principle of the Bibliothèque Nationale de France is to be an urban development. Only the State can grant Paris the funds for clearing an empty space in a 90 hectare district scheduled for 2 million $\mathrm{m}^{2}$ of dense construction.[...] We wanted to plant the seed, if one may say so, from which the neighbourhood might flourish. The intention is not to start building a bunker, a kind of mammoth. [...] We have two choices: either the library is conceived as an Egyptian mastaba where people and books are buried, or we aim for the sky and use height. Balance will be maintained by the presence of the four towers." 18

It seems that no consensus was possible between the architect and librarians in charge of planning. Before the project team engaged itself in the actual planning of the future library, the Tolbiac building had already been given its identity: it was a monument as well as an urban project and had been designed accordingly. In response to a report, submitted by the $\mathrm{CSB}$, warning on the potential problems in terms of library operations, President Mitterrand reconfirmed his architectural choice and added that no significant actions should alter the design (Gattegno, 1992, p. 96).

\section{Assessment of the Tolbiac library}

A study of the literature devoted to the project on the Tolbiac site of the Bibliothèque

Nationale de France ${ }^{19}$ reveals four main areas of debate:

- the size and the design of the building in terms of its functionality as a library and in terms of operational cost;

- the type of targeted reading public;

- the encyclopaedic nature of open access collections;

\footnotetext{
18 Author's translation

${ }^{19}$ The project has been the object of an intensive coverage from the press, specialised as well as the general press. Among the columnists involved, those who have contributed on a regular basis are Pierre Nora, editor of Le Debat and Emmanuel de Roux writing for Le Monde.
} 
- the innovations that the Tolbiac building is designed to carry through.

These four points were all part of President Mitterrand's ambition and have been clearly reinstated on several occasions, every time a compromise was about to alter either the design of the building or the original conception of the library. It is in this light that any discussion of the results achieved by the project teams must take place, acknowledging their efforts to reconcile the idea of a prestigious monument with the requirements of a functional building as well as to translate a dream into reality in the context of the existing French national library.

The fact that the project of the Très Grande Bibliothèque was the personal wish of the French President combined with the fact that the Tolbiac site was gifted by the City of Paris, has strongly influenced the planning of the Tolbiac building and has determined its characteristics. It has given the building a strong element of monumentality with emphasis on its aesthetic and urbanistic role.

In spite of the small amount of specialised literature on the topic of national library design, strong emphasis has been put on the necessity of close collaboration between librarians, architects, civil servants, and politicians in the early phase of a long planning process by the exchange of programmes, briefs, feasibility studies, feedback reports, secondary briefs etc. (Metcalf, 1986; Thomson,1989; Cohen, 1994; Grunberg, 1996). This is not how the officials in charge of the TGB project chose to proceed. The decision to rush into an architectural contest before the completion of the planning process was deliberate. The time scale was dictated by the requirement to complete the construction of the building by the end of President Mitterrand's mandate, that is Spring 1995. This is how barely 13 months elapsed from the announcement of the project to the start of foundation work. According to the official in charge of the overall project until the completion of construction, this method had the advantage of avoiding the succession of lengthy procedures, postponing the completion of the project. He also added, that the method of working within an existing framework determined by the site and the design of the building, was common practice in France. In this matter, his sole responsibility was to fulfil his contract with his superior, the President. (Biasini, 1990)

Once the symbolic aspects of the building were accepted, there seemed to be no other choice than to adopt the following work pattern: the planning management team worked towards solutions on how adapting library functions to the architectural design, while the architect had to modify parts of the original layout to comply with changes in the programme. The most significant change was the decision to move the whole of the printed collection stored in Richelieu to Tolbiac, thus tripling the initial stock of three million books to 10 million. The architect's solution was then to reduce the amount of area for conferences and seminars inside the base to make room for stacks. Also, public access to the sunken garden, central to the architect's conception of the use of the building is not permitted for security reasons.

The 'Très Grande Bibliothèque' that Cahart and Melot had in mind while drawing up their proposals was to be a complementary building to the Richelieu library. This was to satisfy the requirements of the concept of the democratisation of knowledge as well as to ensure the comfort of the traditional researchers. This library was going to accommodate two types of libraries: one for researchers and one for the general public. Original figures were of the following order:

- 1,600 seats for researchers 
- 2,000 seats for the general public

They were already recommending a six fold increase in the capacity of the BN. It meant that, including exhibition and recreational areas, the buildings were to offer $100,000 \mathrm{~m}^{2}$ of usable surface area on the assumption that only collections after 1945 would be transferred from the Richelieu site. In 1992, three years after the architect had submitted his project, seat numbers were finalised at 3,600 and usable surface area at 292,000 $\mathrm{m}^{2}$. The massive increase of usable surface area can be explained by the necessity to operate the two libraries independently, but this seriously delayed the progress made in the interior layout of the building.

One of the traditional principles underlying the planning of a library building with an enclosed collection is to plan library activities around two main areas: either the stacking (e.g. the Causewayside building of the National Library of Scotland) or the reading room(s), (Bibliothèque Nationale at Richelieu). None of these practices have been followed at Tolbiac. Instead, the library has been planned around a garden, which, in itself, has no library purpose, except in providing natural light to the readers of the lower level library.

In an analytic study on the Tolbiac building, the American architect/librarian Leighton (1991) outlines the obstacles encountered by the planning teams in their attempt to make the building functional. The library will have to operate in an 'exploded' but also 'imploded' building of gigantic proportions: the books are to be stored in four high tower stacks positioned at the outer corner of the site, while the reading rooms are underground, looking into the sunken garden. The concentric layout is fragmented in four places by each of the four towers, one at each corner. The angles created by the intersection of horizontal and vertical lines at the level of the esplanade, combined with the 24 corners shaping the towers, together with the 20 corners created by the sunken garden and the sunken alley ways constitute a 44 corner structure, 11 more than a cube, which is supposed to be the ideal shape for a library. This particular design was not only more costly to build but will also increase operating costs in terms of equipment, ventilation and personnel. It is not the intention here to scrutinise each aspect of the library, but some examples will help an appreciation of the cost involved in running such a building, whether it concerns the management of collections or the management of people.

One unlooked for feature in any library building is the two access points. In terms of personnel, it is a costly option, but it is difficult or even impossible to imagine how such a building could operate with a single entrance point. Closing one entrance, during quiet hours for instance, would prevent access to the public restaurants. Unlike the BPI at the Pompidou Centre which can be operational with a minimum of 20 staff (on Sundays and public holidays for instance), the Tolbiac library seemingly will not be able to operate, even partially, with less than 200 staff. This is explained by the fragmentation of services stemming from the division of reading space in duplicate thematic departments.

The layout of the upper level which is aimed to receive the first wave of visitors does not seem to reflect the traditional sequence of actions of library users which usually follows a fan pattern. At Tolbiac, whatever the final destination a visitor may choose, once the admission control has been cleared, he/she has to turn at a right angle. Once engaged on the ambulatory, the visitor may be walking against the flow of the public which have entered the building at the symmetrically opposed entrance. Clear signposting will play an essential role in those circumstances. 
The layout of the stacking towers is composed of plants, staircase entrance, emergency exit, access corridor to stacks, maintenance areas, staff lift, goods elevators, TAD station, temperature control station, staff office etc., repeated on each of the 11 floors in each of the four towers. The multiple of 44 implies substantially increased costs in both operation and construction.

The construction cost of the Tolbiac library has not exceeded the 5.2 billion francs starting budget set up in December 1989, but a survey, conducted by members of the Ministère de la Culture and of the Ministère des Finances, ${ }^{20}$ has revealed that the annual operating budget of the BNF (all sites included) amounts to approximately 1.2 billion francs, which represents $10 \%$ of the overall budget allocated to the Ministère de la Culture. Meanwhile, the French government has reduced the budget for culture by $5 \%$ for 1996 , and plans to continue budget cuts in the years to come (as part of a general public expenditure policy conducted in an effort to qualify France for entry to the European common currency programme). This is reflected in the figures of the proposed budget for 1997-98 which must not exceed 790 million francs. It is feared that such budgetary cuts are likely not only to affect the efficiency of the Tolbiac library, but that they might also hinder the progress of the programmes which are to constitute the 'library of a wholly new conception'.

Presently, running the BNF without Tolbiac costs 860 million francs per year; but to open Tolbiac in its entirety, the ministry needs an extra 100 million francs. This figure does not include the cost of hiring 400 additional staff. This is the area where savings will occur. Reduced staff numbers, because of shortage of funds, is the main reason for a gradual opening. This is having an immediate effect on the pattern of opening hours of the public research library. It is to be opened six days a week (closed on Mondays) from 10 a.m. to 7 p.m. from Tuesdays to Saturdays and from 12 noon to 6 p.m. on Sundays. This compares fairly poorly with the existing opening hours at the Richelieu site (9 a.m. to 8 p.m. from Monday to Friday included and Saturday from 9 a.m. to 5.30 p.m.). The comparison is even more damaging with the BPI which used to open from 12 noon to 10 p.m. 6 days a week and from 10 a.m. to 10 p.m. on Sundays.

The substantial sums needed to run the BNF have put heavy pressures on the politics of the Ministère de la Culture on a national level as well. As expressed by speakers of the Senat (25 Nov. 95), the French nation will accept the budgetary requirement allocated to the BNF as long as it is balanced with equivalent spending in the provinces, not only in the field of library services, but also in all kind of cultural activities. Indeed, the project of the BNF is seen as the result of a highly centralised cultural policy which places Paris at the forefront yet again.

This is why the most pressing issue for Philippe Douste-Blazy, who became Ministre de la Culture in 1995, was to obtain sufficient funds to pursue the implementation of the programmes essential to the success of the BNF, such as the Catalogue Collectif National and the network of 'Poles associés'. For these purposes, the ministry needs a capital budget of 350 million francs, the creation of 560 posts and an annual running budget of 38 million francs. Without those credits, 'we would have built a cathedral in the desert' warned the minister (Sénat, 1995).

\footnotetext{
${ }^{20}$ Although not published, the Hespel/Pattyn report has been widely commented in the press (Lhaik,1996; de Roux,1996, etc.)
} 
Although there is no question of trying to make the library profitable, the Conseil Supérieur des Bibliothèques (1993) is of the opinion that, with such a high running budget, the BNF should endeavour to offer long opening hours to ensure maximal utilisation. However, this wish comes up against a number of difficulties related to the design of the building, staff shortages due to budgetary constraints, and the working regulations of the library profession within public institutions.

The initial confusion about the nature of the future library, whether it would be just a national library, or the national library and the fact that no clarification was given as to the fate of the BN explains why the planning team had difficulties in rationalising the combination of a national library with a reference library open to all public. The idea was not entirely new. As early as 1684, the Bibliothèque Royale became open by decree to the general public 'once a week, from eleven in the morning to one hour after mid-day' (Comte, 1974). These facilities were extended throughout the centuries that followed. To satisfy an increasing demand, the decree of 1858 established the practice of two types of reading facilities by opening two distinct reading rooms: one for specialised researchers and one housing a collection of 20,000 open access books for a less ‘specialised' public (Balayé, 1991).

The Tolbiac project is a revival of the traditional French view of distinguishing two modes of reading practices (Gattegno, 1992). There are readers aiming to create further knowledge from the body of recorded knowledge, the 'institutional researchers' (Renoult, 1995), and those aiming to satisfy a personal intellectual curiosity. This view point has inevitably led to the application of a certain elitism which is now threatened by the introduction of democratisation of knowledge, which implies that the entirety of patrimonial collections should be accessible to all.

The creation of two super-imposed libraries, operating independently (by not having interchangeable collections) is the answer to this dilemma. It has been seen as a compromise to resolve the contradicting missions which, in France, have been fulfilled by different types of institutions, and on different premises (Favier, 1995). At Tolbiac, the aim is to give the inquisitive readers what they need in terms of reference material and reading comfort, without disturbing the specialised researchers. The latter will enjoy the additional facility of being able to consult freely collections aimed to the general public, but the reverse is possible only after clearance granted by a librarian.

The achievement of translating Mitterrand's wish in a situation dictated by the design of the building was praised by the CSB in 1991 as follows:

"A space with open access collections combined with a reading room where heritage collections can be communicated to users, constitutes the particularity and the strength of the Bibliothèque de France.” (Conseil Supérieur des Bibliothèques, 1991, p.18) ${ }^{21}$

However, this particularity raises several questions:

- how to define the general public?

- how should the open access collections be constituted?

It was important for the project teams to identify the different types of users who might visit the Tolbiac building, because, unlike a conventional national library which relies mainly on the collections acquired by legal deposit, the BNF has the ambition to serve a larger public for

\footnotetext{
${ }^{21}$ Author's translation.
} 
which an open access collection has to be selected. A forecast of the reading public of the BNF was summarised by Baudelot and Verry (1994) as follows:

1. Members of the public (4,500 per day) visiting exhibitions, participating to conferences, seminars and those aiming to initiate themselves to bibliographic searching.

2. Among the general public (4,500 per day), those who need to supplement their studies and research with the kind of information found in a reference collection of high academic level. This group might include professionals, academics, postgraduates and $\mathrm{PhD}$ students, journalists. These users would be at least 18 years old and in possession of the Baccalauréat.

3. Those engaged in specialised research (3,000 per day) who can justify their needs for consulting the heritage collections. This group includes the former users of the BN with the addition of a new category of researchers: those in search of the newly acquired scientific, technical and legal documents.

In total, it forecast that the library would serve about 12,000 visitors per day.

However, there will be a fringe group of 'amateur' researchers which may not fit in any of these categories; those, for instance, who may not be sure of the relevance of the heritage collections for their research until they have explored them. It is important here to give those readers the opportunity to access the specialised research library even if their demand is not properly articulated. The peculiarity of research is to explore into the unknown and the very fact that the two types of libraries are operating separately may constitute a barrier to these readers.

The success of the Tolbiac building, and in particular of the public research library, will depend on the quality and the relevance of the open access collections. As mentioned earlier, a policy of intensive acquisition has been engaged in an effort to redress the deficiencies of the $\mathrm{BN}$ in the provision of scientific, legal and foreign works, and with the ultimate objective to create an encyclopaedic tool for research. However, certain criteria of selection have been applied to reflect the contemporary approach to the search of knowledge (Béguet and Hadjopoulou, 1996). Taking the example of scientific literature, one may wonder what level of specialisation should the library aim for? Scientific researchers who represent only 3.5\% of the French research community have already established their habits in terms of documentation supply by using the very efficient services of INIST, and for the less specialised users, such as journalists, the Mediathèque de La Villette has proven to be very useful.

In any case, the decision to expand collections to new disciplines has been perceived as a gamble (Favier, 1995) since it was based on unknown quantities, namely the nature and the number of the new type of reading public that the BNF hopes to attract. Will the management not run the risk of attracting a larger number of users than anticipated, which would lead to the situation whereby the upper level library might become saturated? Then, the temptation to divert those readers to the lower floor might be pressing. In the audio-visual area in particular, the question arises: should the future library limit itself to enhancing the services traditionally geared to the public of the old $\mathrm{BN}$, that is to ensure its continuity while working towards its modernity, or should it seek a different type of public, for instance professionals in the field of the audio-visual industry? The policy of integrating research conducted on audiovisual documents with research from printed material is reflected in the way audio-visual equipment is scattered throughout the library. Even the audio-visual room of the lower level incorporates a collection of 30,000 monographs. Professionals of the audio-visual industry 
will, however, continue to use the newly equipped facilities of the Mediathèque of the Palais de Tokyo, as well as the existing facilities offered by INA and CNN.

In a brochure promoting the BNF (Bibliothèque Nationale de France, 1995), it is stated that the public research library must not act as a substitute for local institutions. However, given the continuing deficiencies of Parisian university libraries, it seems likely that the students using the Richelieu site may just transfer to Tolbiac. Moreover, their numbers may increase because of the temporary closure of the BPI library at the Pompidou Centre for renovation. One can anticipate that the public reference library at Tolbiac might just act as a substitute.

Besides the fact of moving and relocating its collections, the creation of the new Tolbiac library has provided the Bibliothèque Nationale de France as a whole with an opportunity to introduce a number of innovative programmes (Bibliothèque Nationale de France, 1995, p.23). ${ }^{22}$ This statement, in itself, seems to justify the construction of the Tolbiac building. These programmes, such as the Catalogue Collectif National, the cooperation of associated institutions, and the digitisation of an increasing volume of documents should contribute to placing the Bibliothèque Nationale de France at the centre of a national network of remoteaccess services. In what way will the Tolbiac building accommodate these programmes? As early as 1990, the EPBF claimed in one of their promotional brochure that the real 'modernity' of the new institution will be made of a 'network and a machine'. The network refers to the CCF 'Catalogue Collectif de France', and the machine is the PLAO, the 'Poste de Lecture Assistée par Ordinateur’.

As mentioned earlier in this review, the success of Minitel in France has contributed to a rapid development of on-line catalogues of a wide variety of libraries and therefore to their easy and relatively cheap access. Moreover, via INTERNET, the BNF OPALE and OPALINE catalogues are already accessible to an even wider numbers of users from anywhere in the world. It is planned that the Bibliothèque Nationale de France will have a single catalogue of all books, periodicals, sound recordings, audio-visual material, computer products and multimedia material, totalling 8 million bibliographic records. The catalogue will eventually include all items in the specialised collections in the Richelieu building: manuscripts, prints, maps, coins, music etc. The catalogue will be directly linked to all communication and acquisition functions, and will also be the keystone of the French Union catalogue. However, on opening of the Tolbiac building, users of the upper level library will have no need for sophisticated equipment, since the collection of 180,000 open access volumes will be catalogued on a CD-ROM.

The PLAO is a computerised reading station which will present digitised documents in an hypertext mode. The user will be able to study these documents in an interactive way, using conventional methods of scientific reading, such as underlining texts, note marking, cross references etc. These actions can be saved in the programme and downloaded onto portable computers. The user will be able to request the scanning of additional documents. The success of PLAOs will be closely associated with the availability of the largest possible volume of digitised documents. For the planners of the BNF, the digitisation of documents is seen as an other way to reach the encyclopaedic ideal. According to Maignien and Virbel (1996), the presentation of digitised documents in hypertext mode can be compared to the $18^{\text {th }}$ century French philosophers' ambition to encompass all aspects of knowledge in an

\footnotetext{
${ }^{22}$ Author's translation.
} 
encyclopaedia format, so that the reader is able to widen his/her perspective of a particular topic by creating associations of ideas.

The digitisation of documents, however, is not without its problems. Firstly, the high cost of this technique may be prohibitive. According to Cahart and Melot's estimates, the future library would need to spend in excess of 100 million francs to digitise 300,000 texts.

Secondly, criteria of selection are and will always be difficult to define, especially if the main objective of digitisation in the context of the BNF is not primarily a method of preservation, but rather a mean to create an encyclopaedic presentation of collections (Richard, 1993; Maignien, 1996). The BNF must reflect seriously on what will make the digitisation of its documents worthwhile. This is an important consideration as the use of PLAO will be fee paying. Finally, the great unknown quantity remains to know how popular and even feasible searching on hypertext mode will prove to be on a large scale.

\section{An initial evaluation}

As the 1994 legislation stipulated, the Bibliothèque Nationale de France is the national library of France. It has inherited all the BN's attributes and problems: exhaustive legal deposit; heterogeneous collections; the complex layout and unsuitable buildings of the Richelieu site; decentralisation of non-lending sites; deficiencies in computing facilities and in document supply services. However, while carrying out the same functions as the former BN, the BNF is now also charged with working towards the completion of the goals set out by President Mitterrand.

It is too soon to suggest that the Tolbiac building may become the symbol of the French national library. In any case, this was not envisaged at the outset of the project because, as early official documents demonstrate, the Tolbiac library was not conceived in terms of a national library but rather for the sake of 'modernity'. Today, the Tolbiac library is seen as the embodiment of President Mitterrand's dream. Hence the decision to name it after him. Given the French political context of presidential government, this is not surprising in itself. The fact that the French President can satisfy a whim on this scale is the ultimate proof of his authority. Examples abound, and in the field of architecture and urban planning, the cultural tastes of successive presidents have always been evident: Pompidou, for example, had the Centre Beaubourg built in the revolutionary Paris, while Giscard d'Estaing personally insisted on the transformation of the disused Orsay railway station into an art gallery. Mitterrand, himself, made the Ministère des finances vacate those parts of the Louvre it occupied to make way for an extension of the museum, and he also gave the go ahead for the building of an Opera house at the Bastille and a major science museum at La Villette. At the time of his reelection in 1988, the President's 'Grands Projets' in Paris were increasingly visible manifestations of his first mandate.

The Tolbiac project initially combined, behind the vague notion of the 'Très Grande Bibliothèque', three sets of different and even contradictory ideas:

- an extension to the old Bibliothèque Nationale (in transferring only monographs published after 1945);

- a virtual library comprising an on-line union catalogue with the supply of digitised documents;

- a public library open to all. 
However, since the concept underlying the 'Très Grande Bibliothèque' became the Bibliothèque Nationale de France by law, it is appropriate here to apply a different set of criteria to assess the Tolbiac building in relation to the role of a modern national library.

It is probable that any building, however ill designed for its purpose, can be made functional, but at a cost. Just as the officials attempted to assert an element of professional judgement into the planning of the building, it can be assumed that further efforts will continue throughout the life of the building to modify it to meet changing requiremnts. This review has brought out some elements of unknown quantities in the future of the building, such as the type of users who will visit the public reference library and the impact of technical innovations which have not yet been tried in such an environment. In the short term (so long as the patrimonial collections remained at the Richelieu site), the role of the Tolbiac library in achieving the goals set for the Bibliothèque Nationale de France ws very limited. Indeed, it was no more than an open access public reference library offering approximately 420,000 documents on open access ${ }^{23}$, and with limited (and initially unreliable) information technology.

Although it was planned to link the TGB (and subsequently the BNF) to the existing French library networks, the project was allowed to progress without providing alternative means to address other problems specific to the French library context, such as the deficiencies of university libraries, or the lack of public reference services, especially in the Paris area. This may explain the decision to set up a public reference library on the higher level of the Tolbiac building. However, it could be argued that, in this respect, the BNF is taking on responsibilities which should fall within the competence of other authorities, such as the City of Paris and the Ministère de l'enseignement supérieur. Indeed, the initial impact of the opening of the public reference library in the Tolbiac building was felt only by the researchers currently working on the BNF's Richelieu site, who since December 1996 found the services there greatly improved thanks to the departure of some of the students of the Parisian universities who chose to conduct their studies at Tolbiac.

With the opening of the lower level research library and the transfer of other functions from rue Richelieu, the Tolbiac building is equipped to fulfil more of the functions of a national library building.

Through the implementation of a series of innovative programmes, the 'new' French national library is intended to become the 'hub' of a national and international bibliographic network in order to communicate its collections to the largest possible public. Since all the printed stock has been gathered at Tolbiac, communication and consultation of collections are greatly improved by the vast increase in on-site storage space, in the number of seats, and in the use of modern technology. With the move of all printed collections to the new building, long overdue projects such as stocktaking of ancient collections, updating and computerisation of catalogues have been given the necessary funds to go ahead. This should go a long way towards fulfilling Humphreys' and de Solan's views of the roles of the contemporary national library.

The Tolbiac site has taken over the traditional functions of a national library such as the management of legal deposit and national bibliography, away from the congested working conditions of the Richelieu site. However, in areas such as conservation, the Tolbiac building

\footnotetext{
${ }^{23}$ A much lower figure than the 300,000 documents planned.
} 
plays a minimal role as these activities will remain decentralised in Provins and Sablé and in the new centre of Marne-la-Vallée. Similarly, the centre at Marne-la-Vallée will also act as the depository for one copy of all national publicaications. Given the high cost of city centre sites and associated labour costs, these decision cannot be criticised.

The distribution of the capital budget which prioritised the construction of the building might prove, in the end, to be harmful to the image and the effectiveness of the Tolbiac library itself. It has created a time-lag between the completion of the Tolbiac building and the progress of the associated programmes towards the creation of an on-line library network. The effectiveness of the Tolbiac library as a national bibliographic centre will be limited until the French on-line union catalogue has been set up, or an alternative network of OPACs has been put in place. Similarly the development of BNF as a virtual library, along the lines recommended by Etheredge, is dependent not only on significant additional funding to digitise appropriate parts of its own collection and of other libraries', but also on the implementation of a plan for the networking of libraries throughout the country, due to be completed in 2000, so that their users can access this material. Until then, the BNF is not reassuming any responsibilities for document supply, which were performed by the Versailles lending centre until its closure. The decision to rely on other libraries, particularly on the network of CADISTs, for document supply services implies the existence of a fairly comprehensive on-line national union catalogue, which is not yet in place. Furthermore, since the capital budget has been exhausted, these programmes are no longer sustained by a long term budgetary policy. The allocation of funds, being debated in the 'Parlement' on a yearly basis, is likely to develop in an ad hoc manner, according to the political and economic priorities of the time, and is, therefore, likely to jeopardise the future of the Tolbiac library as it has been envisaged.

Moreover, Cornish's recommendations (1991, p. 88) that a national library should become the hub of librarianship are likely to be hindered by the prohibitive annual running cost of the Tolbiac building, estimated at 1,000 million Francs. Indeed, these recommendations imply the support of a sustained budget to be able to recruit and retain a large number of skilled staff to ensure that the BNF can perform that role by 'providing national leadership in library and information affairs' as well as a 'national information system to facilitate economic and social development at both national and international levels'. During a period when the French government believes it necessary to impose strict budgetary austerity, it is difficult to credit the possibility that the BNF can be sure to have sufficient staff and expertise to take the lead in library development.

The TGB project provides a good example of the difficulties involved in creating an appropriate national library in a particular context. The French people have a very clear sense of their cultural and linguistic identity thanks to the successive policies of a centralised government in the field of education in particular and it can, therefore, be seen as the right political decision to build a 'monument' to symbolise the French national heritage. However, in this particular case, this monument has proven to be extravagant in terms of operating cost because of its architectural design and the dual role which was assigned to it. It is likely to jeopardise the associated programmes devised to carry on that heritage into the next century and to make the benefits available throughout the country. Contemporary researchers do not demand a monument to work in; they require easy access to bibliographic information and an efficient document supply system. These services, because they are supported by an ever changing technology, require an integrated information and budgetary policy which must include the rest of the French library network so that investments can return their potential in 
full; otherwise the Mitterrand library will, indeed, be a 'cathedral in the desert' and unable to contribute to fulfilling the BNF's functional role in the $21^{\text {st }}$ century.

\section{AUTHORS}

Sylvie Davies, a graduate of the Sorbonne, is a Research Assistant in the School of Information and Media, where she gained her Masters degree in Information and Library Studies in 1997.

Ian Johnson has been Head of the School of Information and Media since 1989. He has been Chairman of the Professional Board of IFLA, 1993 - 1995, and is currently Chairman of the Heads of Schools and Departments Committee of BAILER: the British Association for Information and Library Education and Research, and of the Executive Board of EUCLID: the European Association for Library and Information Education and Research.

\section{BIBLIOGRAPHY}

ATTALI, J. (1995) Verbatim III, 1988-1991. Paris: Fayard.

BALAYÉ, S. (1991) Histoire des bibliothèques françaises. Genève: Promodis- ECL.

BAUDELOT, C., and C. VERRET. (1994) Profession: lecteur. Résultat d'une enquête sur les lecteurs de la BNF. Bulletin des bibliothèques de France, 39 (4), pp. 8-17.

BÉGUET, B., and HADJOPOULOU, C. (1996) Les Collections en libre accès de la Bibliothèque Nationale de France. Bulletin des Bibliothèques de France, 41 (4), pp. 40-46.

BERTRAND, A.M. (1994) Les bibliothèques municipales: acteurs et enjeu. Paris: Editions du Cercle de la Librairie.

BIASINI, E. (1990) Playdoyer pour une méthode. Le Débat. No. 62, Nov-Dec, pp. 151-156.

Bibliothèque de France (1989) Concours international d'idées, esquisse de programme. Paris: Ministère de la Culture, de la Communication, des Grands Travaux, Secrétariat d'état aux grands travaux, Association pour la Bibliothèque de France.

Bibliothèque de France (ed.) (1990) Bibliothèque de France: le projet, le rapport du groupe de travail. Paris: Etablissement public de la Bibliothèque de France.

Bibliothèque de France (ed.) (1990), Bibliothèque de France: les rapports des groupes de travail. Paris: Etablissement public de la Bibliothèque de France.

Bibliothèque de France (1991), Rapport des groupes de travail 1991. Paris: Etablissement public de France

Bibliothèque de France (ed.) (1992), Bibliothèque de France, les résolutions d'octobre: les espaces de lecture et de recherche. Paris: Ministère de la Culture et de la Francophonie.

Bibliothèque de France (1992), La Lettre d'information. No 8, Dec. 92, p.3.

Bibliothèque Nationale de France, URL: http://www.bnf.fr

Bibliothèque Nationale de France (1996) Actualités de la Bibliothèque Nationale de France. No.3, Jan-FebMarch, pp. 4-5. 
Bilan sur la Bibliothèque Nationale de France, Trajectoire, March 1994.

BLASSELLE, B. (1993) La Bibliothèque Nationale. Paris: Presses Universitaires de France.

British Library. (1995) Advisory Committee for Bibliographic Services, Progress Report on CoBRA. BS AC 95/05 (Typescript).

BROPHY, P. (1995) Opportunities for libraries in Europe (OPLES). London: British Library Research and Development Department, (Library and Information Research Reports 103).

CAHART, P., and MELOT. M. (1989) Propositions pour une grande bibliothèque. Paris: La Documentation française.

CALENGE, B. (1992) Réseaux à facettes. Bulletin des Bibliothèques de France, 37 (5), pp. 12-23.

CARBONE, P. (1992) Les bibliothèques universitaires: dix ans après le rapport Vandevoorde. Bulletin des Bibliothèques de France, 37 (4), pp. 46-58.

CHEVALLIER, A. (1993) Les relations internationales de la Bibliothèque de France. Bulletin d'information de la $A B F, 158$, pp. 7-13.

COHEN, E. (1994) The architectural and interior design planning process. Library Trends, 42 (3), pp. 547-563.

Commission of the European Community (1987) DGXIII, Plan of action for libraries. Luxembourg: CEC.

COMTE, H. (1977) Les Bibliothèques publiques en France. Lyon: Presses de l'Ecole Nationale Supérieure des Bibliothèques.

Conseil Supérieur des Bibliothèques, (1996) Rapport du président pour l'année 1995. Paris: Association du Conseil Supérieur des Bibliothèques. URL: http://www. Grenet.fr/redoc/csb.

CORNISH, G. P. (1990) Interlending and document supply in Europe. Paris: UNESCO (PGI-90/WS/13)

CORNISH, G. P., (1991) The role of national libraries in the new information environment. Paris: UNESCO (PGI/91/WS4).

Direction du livre et de la lecture. (1995) Bibliothèques départementales de prêt: données 1993 et 1994. Paris: Ministère de la Culture et de la francophonie.

Direction du Livre et de la Lecture (1996) Bibliothèques municipales: données 94, Paris: Ministère de la Culture et de la francophonie.

ELDERMAN, F., and De ROUX, E. (1991) L’architecte et les frelons. Le Monde, 14 Novembre, p.9.

ESDAILE, A. (1934) National libraries in the world. London: Grafton and Co.

Etablissement de la Bibliothèque de France (1992), Synthèse de programme de la Bibliothèque de France. Paris: Ministère de la Culture et de la Francophonie.

ETHEREDGE, L.S. (1994) National knowledge strategies and the library of the future. FID News Bulletin, 44(7/8), pp. 142-145.

Europa Web, URL: http://europa.eu.int.

European Association of Information Services (1996). Inist. Newsidic, No 129, Jan/Feb, p. 9.

European Commission. (1995) Directorate General XIII, Telematics Applications Programme 1994-1998, Background Notes. Feb. 1995. 
FAVIER, J. (1995) Où en est la Bibliothèque Nationale de France? Le Débat, No 94 July-August, pp. 143-149.

GASCUEL, J. (1984) Un espace pour le livre: guide á l'intention de tous ceux qui créent, aménagent ou renovent une bibliothèque. Paris: Editions du Cercle de la Librarie.

GATTEGNO, J. (1992) La bibliothèque de France à mi-parcours: de la TGB à la BN bis? Paris: Editions du Cercle de la Librairie.

GREEN, S. (1979) The British Library, 뜨 : National Libraries edited by M. Line. London: Aslib.

GRIFFITHS, J,M. (1993) Information access in the emerging global network, in: Proceedings of the International Conference on National Libraries towards the $21^{\text {st }}$ century, Taipei, 20-24 April 1993. Taipei: National Central Library, pp. 667-691.

GROSBOIS, L. (1989) Handicap physique et construction. Paris: Le Moniteur.

GRUNBERG, G. ed. (1996) La Bibliothèque dans la Cité. Paris: Le Moniteur.

HIGONNET, P. (1990) A French folly. Times Literary Supplement, 11-17 May, pp. 14-15.

HOARE, P. (1996) Legal deposit of non-print material, an international overview, Sept.-Oct. 95. British Library Research and Development Department. Report 6245.

HUMPHREYS, K.W. (1966) National library functions, Unesco Bulletin for Libraries, 20 (4), July-August 1966.

HUMPHREYS, K.W. (1988) A national library in theory and in practice. London: The British Library (The Panizzi Lectures).

JULLIARD, J. (1989) Monsieur le President... Le Nouvel Observateur. 22-28 June, p. 37.

IFLA. URL: http://www.nlc.ca/ifla/home.html

KESSLER, J. (1994) French libraries online - electronic Hachette? The electronic library. 12 (2), pp.79-87.

LAMBERT, M. (1989) Les bibliothèques specialisées , Livres Hebdo, No 32-35, pp. 56-64.

LEIGHTON, P. (1991) Un regard analytique sur la Bibliothèque de France , Le Débat, No.65, May-August, pp. 234-252.

Le RIDER, G. (1991) Contre les tours-magasins, Le Monde, 10 Oct, p. 23.

LHAIC, C. (1996) Menace sur un grand projet. L'Express, 4 July 1996, pp. 80-83.

LIEBER, C. (1992) La Bibliothèque publique d’information, Bulletin des Bibliothèques de France. 37, (4), pp. 22-23.

LINE, M.B. (1990) Do we need national libraries, and if so what sort? Alexandria, 2 (2), July, pp. 27-38.

LUNN, J. (1981) Guidelines for legal deposit legislation. UNESCO General Information Programme and UNISIST. PGI81/WS/23.

MAIGNIEN, Y., and VIRBEL, J. (1996) Vers un nouvel encyclopédisme? Actualités de la Bibliothèque Nationale de France. No. 4, April-June.

MANZONI, M., ed. (1992) A synthesis on Legal Deposit and its Practice in the EC Member States. European Commission. Directorate-General XIII. 
MEARNS, D.C. (1955) Current trends in national libraries. Library Trends, 4 (1), July, pp. 96-104.

MELOT, M., ed. (1996) Nouvelles Alexandries. Paris: Editions du Cercle de la librairie.

METCALF, K. (1986) Planning Academic and Research Library Buildings. Second edition by P.D. Leighton and D.C. Weber. Chigago and London: American Library Association.

MEYRIAT, J. (1986) La France- a-t-elle une politique de l’information? Aslib Proceedings, 38 (6-7), pp. 205214.

Ministère de la Culture, de la communication, des grands travaux et du bicentenaire, Secretariat d'Etat aux grands travaux, Association pour la Bibliothèque de France. (1989) Bibliothèque de France: Concours international d'idées, esquisse de programme.

Ministère de la Culture (1989) Decret No 89-777 portant la création de l’Etablissement public pour la Bibliothèque de France. Paris: Journal Officiel de la République française (13 octobre 1989).

Ministère de la Culture (1992) Loi No.92-546 relative au dépôt légal Paris: Journal Officiel de la République française (23 Juin 1992).

Ministère de la Culture et de la francophonie, (1993) Décret No. 93-1429 relatif au dépot légal. Journal Officiel de la République française (31 Decembre 1993), pp. 62-66.

Ministère de la Culture et de la francophonie (1994) Decret No 94-3 portant la création de la Bibliothèque Nationale de France. Journal Officiel de la République française (3 Janvier 1994) pp.149-152.

Ministère des affaires étrangères, (1995) France. Paris: Documentation française.

MIQUEL, A. (1989) Les bibliothèques universitaires: rapport au ministre d'Etat, ministre de l'Education nationale, de la Jeunesse et des Sports. Paris: Documentation Française.

NETZER, M. (1989) The network of libraries in the city of Paris, Livres Hebdo, 32-25, pp. 44-46.

NORA, P. (1989) Quelle très grande bibliothèque? Le Débat, 55, May-July, pp. 136-189.

NORA, P. (1990) Dans le bon sens. Le Débat, No. 60, Nov-Dec, pp. 78-96.

PERRAULT, D. (1989) Une place pour Paris, une bibliothèque pour la France: premiers volumes. Paris: Institut français d'architecture.

PERRAULT, D. (1991) Les contraintes et les garanties: réponse à P. Leighton. Le Débat, 65. Mai-Auot, pp. 253-256.

PICHERAL, B. (1982) Le dépôt légal français en 1981. LIBER Bulletin, 18, pp. 16-21.

POULAIN, M. (ed.) (1992) Histoire des bibliothèques françaises. Vol. 3: Les bibliothèques au xx ${ }^{e}$ siècle $1914-$ 1990. Paris: Editions du Cercle de la Librairie.

RENOULT, D. (1990) Vers de nouveaux rapports entre l'Etat et l'Université. Bulletin des Bibliothèques de France, 35 (2), pp. 90-95.

RENOULT, D., et al. (1994) Les Bibliothèques dans l’Université. Paris: Cercle de la Librairie.

RICHARD, M. (1993) Le programme numérisation de la Bibliothèque de France. Bulletin des Bibliothèques de France, 38 (3), pp. 53-63.

ROUX, E de. (1992) Les experts préoccupés. Livres Hebdo, (4), 24 Janvier, p. 23-24.

ROUX, E de. (1996) Les ultimes chantiers de la Bibliothèque Nationale de France. Le Monde, 2 Octobre , p. 13. 
SAUVAGEAU, P. (1991) Les grandes bibliothèques, leur mission et leur insertion dans le paysage documentaire. Documentation et Bibliothèques, 37 (3), July/September, pp. 95-98.

Sénat. (1995) Débats parlementaires, Compte rendu intégral de la séance du 27 novembre 1995. Journal Officiel de la République française, pp. 445-472. URL: http://www.senat.fr

SOLAN de, O. (1995) Les documents informatiques et l'avenir du dépot legal. Bulletin des Bibliothèques de France, 40 (4), pp. 28-31.

THOMPSON, A. (1975) National library buildings: proceedings of a colloquium. Münich: Verlaf Dokumentation.

THOMPSON, G., (1989) Planning and design of library buildings. (3rd ed). London: Butterworth \& Co.

UNESCO. (1960) National Libraries: their problems and prospects. Symposium on national libraries in Europe, Vienna, 1958. Paris: UNESCO.

UNESCO (1974) National Information Systems (NATIS). Paris: UNESCO (COM74/NATIS/3).

UNESCO. (1977) International Congress on Universal Availability of Publications, Final Report. Paris: UNESCO (PGI/77/UAP/3).

WAINWRIGHT, E. (1993) The national library in an electronic age: dinosaur or catalyst? Alexandria, 5 (2), pp. 112-117.

WUEST, R. (1994) From national libraries to the global village library: networks offer new opportunities for traditional libraries. IFLA Journal, 19, pp. 385-390.

ZILLHARDT, S. (1996) CoBRA: une action concertée entre bibliothèques nationales. Bulletin des bibliothèques de France, 41 (1), pp. 66-72. 